\title{
Effect of thigh muscle fomentation on metabolic and inflammatory biomarkers
}

\author{
Masayo Nagai ${ }^{1,2}$, Yoshio Morita ${ }^{2}$, Maiko Mori ${ }^{1}$, Reiko Sakashita ${ }^{1}$ and Hidesuke Kaji ${ }^{1 *}$ \\ ${ }^{1}$ Division of Physiology and Metabolism, University of Hyogo, Akashi, Japan \\ ${ }^{2}$ Department of Nursing, Baika Women's University, Osaka, Japan
}

\begin{abstract}
Fomentation is positioned as one of the thermotherapies. It is already known that warm temperature stimulus to a part of the body will have an effect throughout the body. However, no consensus has been reached on the internal effects of fomentation on the body and systemic metabolism, and no study has been conducted. The present study examined the effects of fomentation on metabolic and inflammatory biomarkers by applying thermal sheets to thigh skeletal muscles. The study subjects were twelve healthy people. The men were $34.5 \pm 3.9$ years old (mean \pm SD, $n=6$ ) and had a BMI of $21.18 \pm 2.5$. The women were $34.3 \pm 3.7$ years old $(n=6)$ and had a BMI of $20.2 \pm 2$. All the subjects were asked to apply thermal loads to the skeletal muscles of their thighs for ten weeks ( 8 hours per day, 5 days per week) using thermal sheets. The following plasma levels before and after the fomentation were measured and compared in the study subjects; fasting glucose, insulin, adiponectin, soluble form of urokinase type plasminogen activator receptor (suPAR) and high sensitive C-reactive protein (hsCRP). Following the application of the thermal sheets, a significant increase was noted in serum adiponectin $(18.6 \pm 7.64$, vs. $15.73 \pm 6.16 \mu \mathrm{g} / \mathrm{ml}$, p=0.033), but no significant change was noted in the fasting serum insulin $(7.47 \pm 4.04 \mu \mathrm{IU} / \mathrm{ml}$ vs. $5.77 \pm 3.12, \mathrm{p}=0.117)$, fasting serum glucose concentrations $(95.42 \pm 6.19$ vs. $93.25 \pm 8.39$, $\mathrm{p}=0.13)$, and in the HOMA-IR $(1.75 \pm 0.91$ vs. $1.35 \pm 0.83, \mathrm{p}=0.099)$. On the other hand, following the application of the thermal sheets, a significant decrease was noted in the serum $\operatorname{suPAR}(0.73 \pm 0.49 \mathrm{ng} / \mathrm{ml}$ vs. $1.62 \pm 0.9 \mathrm{ng} / \mathrm{ml}, \mathrm{p}=0.046)$ in women, although no significant change was noted in the serum hsCRP levels $(760.2 \pm 1221.6 \mathrm{ng} / \mathrm{ml}$ vs. $304.3 \pm 287.5$, p=0.686). Fomentation applied to the skeletal muscles using thermal sheets caused significant elevation of serum adiponectin levels, although insulin sensitivity did not change. In women, fomentation caused a reduction in plasma suPAR levels, suggesting anti-inflammatory or fibrinolytic roles.
\end{abstract}

\section{Introduction}

Fomentation is already known that warm temperature stimulus to a part of the body will have an effect throughout the body. Recent previous reports have indicated that a thermal sheet can be used for simple fomentation, and can be used at the bedside or in the house [1]. However, no consensus has been reached on the internal effects of fomentation on the body and systemic metabolism, and no study has been conducted to examine the effects on metabolic and inflammatory biomarkers.

Heat therapy, which activates the heat-shock protein (HSP) 72, improves clinical parameters in type 2 diabetes. HSP72 expression in skeletal muscle improved insulin resistance [2]. Elevating temperatures lead to activation of the heat-shock response in a variety of tissues including the vasculature [3]. The present study examined the effects on metabolic and inflammatory biomarkers of thermal loads produced by applying thermal sheets to the skeletal muscles of the thighs. Adiponectin protects cardiovascular health [4]. Adiponectin receptors are particularly abundant in skeletal muscles and the liver [5]. Changes in the fluidity lipids induced by the high temperature may cause signal transduction that would induce a cellular heat-shock response such as direct stimulation of adipokine expression by greater HSP expression [6]. Our hypothesis is that this application of thermal sheets may affect plasma levels of adiponectin as a metabolic biomarker. It is also expected that this application might improve skeletal muscle functions due to the increase in the blood flow and improve glucose metabolism. The urokinase-type plasminogen activator receptor (UPAR) is a multifunctional glycoprotein, and the expression is increased during inflammation [7-9]. The soluble form of uPAR (suPAR) takes part in various immunological functions, including cell adhesion, migration, chemotaxis, proteolysis, immune activation, tissue remodeling, invasion and signal transduction [9]. suPAR also plays a role in atherogenesis by orchestrating cellular adhesion, migration, and proliferation during development of atherosclerotic plaque [10]. The current gold marker of low-grade inflammation is high sensitive C-reactive protein (hsCRP), which is measured by a sensitive assay of low levels of the acute phase protein CRP [11]. The value of suPAR is independent of hsCRP levels in predicting future death and myocardial infarction, suggesting that these biomarkers reflect activation of different pathophysiological pathways [12]. Therefore both plasma suPAR and hsCRP levels were evaluated as inflammatory biomarkers.

\section{Materials and methods}

The study subjects were twelve healthy people. The men were $34.5 \pm 3.9$ years old (mean $\pm \mathrm{SD}, \mathrm{n}=6$ ) and BMI of $21.18 \pm 2.5$. The women were $34.3 \pm 3.7$ years old (mean $\pm \mathrm{SD}, \mathrm{n}=6$ ) and with a BMI of $20.2 \pm 2$. They had no history of metabolic disorders. The study subjects were asked to apply thermal loads to the skeletal muscles of their thighs for ten weeks ( 8 hours per day, 5 days per week) using thermal sheets. Fomentation was performed using a heat and steamgenerating (HSG) sheet (Kao Corporation Japan). The HSG sheet produces a heat of about $40^{\circ} \mathrm{C}$ during 5-8 hours. When the HSG sheets

Correspondence to: Hidesuke Kaji, Division of Physiology and Metabolism, University of Hyogo, 13-71, KitaOhji-cho, Akashi, Japan, E-mail: hidesuke_kaji@cnas.u-hyogo.ac.jp

Key words: fomentation, adiponectin, suPAR, hsCRP

Received: June 26, 2015; Accepted: June 29, 2015; Published: July 03, 2015 
were applied, the mean skin temperature under the sheets increased by $4-5^{\circ} \mathrm{C}$ from the baseline and remained at $38-39^{\circ} \mathrm{C}$ throughout the 4-hour application period [1]. Prior to and following the fomentation, plasma fasting levels of glucose were measured by hexokinase UV, insulin by chemiluminescence enzyme immunoassay, adiponectin and suPAR by enzyme-linked immunosorbent assay, and hsCRP by latex agglutination turbidimetry. HOMA-IR was calculated as insulin sensitivity index by the formula; fasting plasma glucose $\mathrm{x}$ insulin/ 405 .

Statistical significance was assessed using Wilcoxon matched-pairs signed-rank test using the "IBM" SPSS" Statistics Desktop version. The study was approved and monitored by the human investigation committee of the Baika Women's University.

\section{Results}

Following the application of thermal sheets, a significant increase was noted in the serum adiponectin $(\mu \mathrm{g} / \mathrm{ml})($ mean $\pm \mathrm{SD}, \mathrm{n}=12$; after

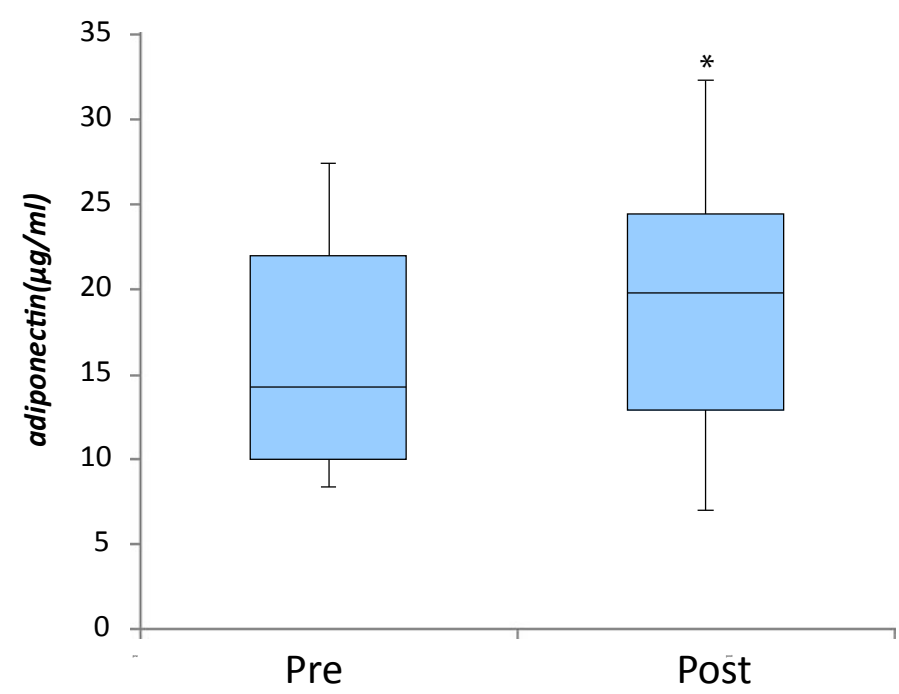

Figure 1. Effect of fomentation on plasma adiponectin levels.

Following the application of thermal sheets, a significant increase was noted in the serum adeponectin $(\mathrm{n}=12)\left(\right.$ mean $\left.\pm \mathrm{SD} ; 15.73 \pm 6.16 \mu \mathrm{g} / \mathrm{ml} v \mathrm{~s} .18 .6 \pm 7.64 \mu \mathrm{g} / \mathrm{ml}, \mathrm{p}=0.033^{*}\right)$

(a)

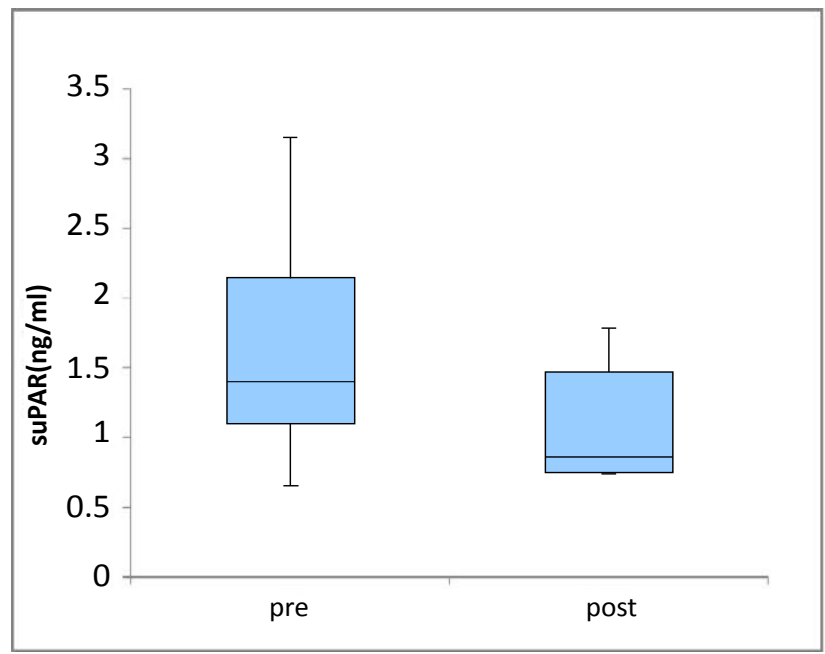

Figure 2. Effect of fomentation on plasma suPAR levels in all subjects (a), and in female (b)

Following the application of thermal sheets, no significant change was noted in the serum suPAR ( $\mathrm{n}=12)$ (mean $\pm \mathrm{SD} ; 1.79 \pm 1.15 v \mathrm{~s}$. $1.4 \pm 1.65$, $\mathrm{p}=0.099)$, but a significant decrease was noted in female $(\mathrm{n}=6)\left(1.16 \pm 0.86 \mathrm{ng} / \mathrm{ml}\right.$ s. $\left.0.77 \pm 0.43 \mathrm{ng} / \mathrm{ml}, \mathrm{p}=0.046^{*}\right)$.
$18.6 \pm 7.64, v s$. before $15.73 \pm 6.16, \mathrm{p}=0.033$ ) (Figure 1$)$. However, no significant change was noted in fasting serum insulin concentrations $(\mu \mathrm{IU} / \mathrm{ml})(7.47 \pm 4.04$ vs. $5.77 \pm 3.12, \mathrm{p}=0.117)$, fasting serum glucose concentrations $(\mathrm{mg} / \mathrm{dl})(95.42 \pm 6.19$ vs. $93.25 \pm 8.39, \mathrm{p}=0.13)$ or in the HOMA-IR $(1.75 \pm 0.91$ vs. $1.35 \pm 0.83, \mathrm{p}=0.099)$. Following the application of thermal sheets, no significant change was noted in the serum $\operatorname{suPAR}(\mathrm{ng} / \mathrm{ml})(\mathrm{n}=12 ; 1.79 \pm 1.15$ vs. $1.4 \pm 1.65, \mathrm{p}=0.099)$ (Figure 2.a). However, a significant decrease was noted $(\mathrm{n}=6 ; 0.73$ \pm 0.49 vs. $1.62 \pm 0.9, \mathrm{p}=0.046$ ) in women (Figure $2 \mathrm{~b}$ ). There was no significant change of plasma hsCRP levels ( $\mathrm{ng} / \mathrm{ml}$ ) (all subjects, $\mathrm{n}=12$; $942.4 \pm 1196.4$ vs. $367.6 \pm 385.3, \mathrm{p}=0.328$, and women, $\mathrm{n}=6$; $760.2 \pm$ 1221.6 vs. $304.3 \pm 287.5, \mathrm{p}=0.686$ ).

\section{Discussion}

In the present study, thermal sheets applied to the skeletal muscles increased serum adiponectin levels, although body weight was not changed during the application of thermal sheets. The serum adiponectin concentration inversely related to BMI and the amount of adipose tissue [13,14], although the mechanism of this inverse relation remained unclarified. In the present study, fasting plasma glucose, insulin and HOMA-IR were not significantly changed despite plasma adiponectin elevation, so it is unlikely that insulin sensitivity was improved in this period. The previous study showed that insulin resistance was not directly associated with plasma adiponectin levels in healthy adults [15]. The serum adiponectin levels are well known to be stable in healthy people, but there was no report regarding the effect of intervention on the association between serum adiponectin and HOMA-IR in healthy people.

Circulating adiponectin levels are strongly inversely correlated with insulin resistance and risk of type 2 diabetes, but the causal relationship of these associations are unclear [16], and these trends were inconsistent with recent reports. The relation between serum adiponectin and HOMA-IR is controversial in previous intervention studies $[17,18]$. Thermal sheets applied to the skeletal muscles did not significantly change plasma suPAR values, but significantly decreased plasma suPAR in women. The reduction of suPAR in women might be an anti-inflammatory effect by fomentation. The uPAR is a multifunctional glycosyl-phosphatidylinositol (GPI)-linked

(b)

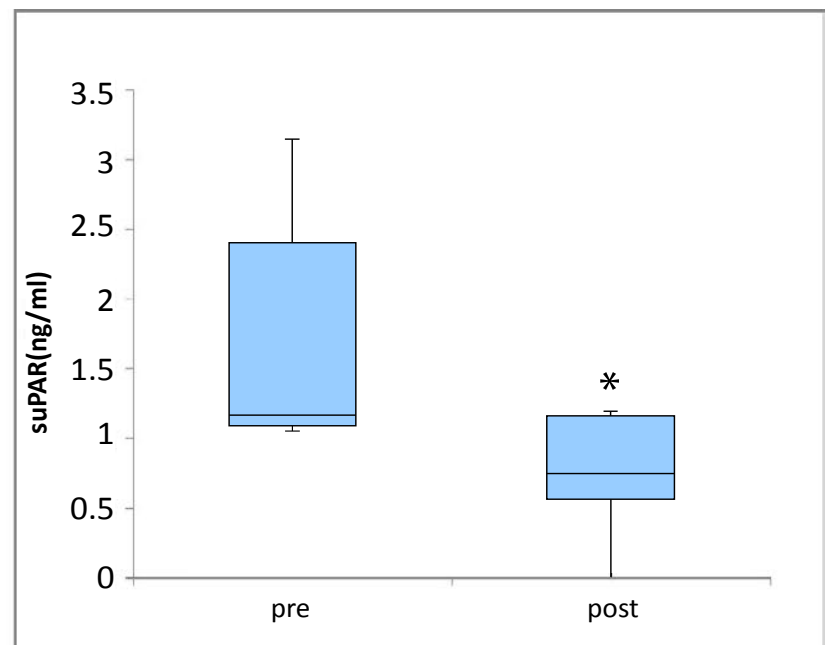


membrane protein. The UPAR is present as membrane-bound form in various immunologically active cells [9]. The suPAR mediates a chemotactic effect on immunologically active cells, but the regulation of the receptor cleavage and hence generation of chemotactic suPARfragments is still not fully understood [9]. The hsCRP concentration was not significantly changed following the application of thermal sheets. Since suPAR is reported to reflect an inflammatory response more extensively than hsCRP [9], we cannot exclude the possibility that the serum suPAR reduction could reflect an anti-inflammatory effect by fomentation in women. The previous study shows that suPAR concentrations positively correlates with gender-specific variation where higher serum concentrations are present in females compared to males [19]. Another possibility explaining the reduction of suPAR is increased fibrinolysis by fomentation. The suPAR is involved in the plasminogen-activating pathway [20]. The down-regulation of suPAR observed in this study may cause the increased free available plasminogen-activator in plasma, thereby inducing fibrinolysis in women.

Additionally, plasma suPAR correlates with important features of dysmetabolism, including the number of white cells, TNF- $\alpha$, fat distribution, insulin sensitivity, insulin or proinsulin secretion, glucose tolerance, and serum lipids in HIV-infected patients. In our study, plasma suPAR levels did not correlate with plasma glucose and adiponectin levels or HOMA-IR in healthy people.

\section{Conclusion}

Fomentation applied to the skeletal muscles using thermal sheets caused significant elevation of serum adiponectin levels, although insulin sensitivity did not change. In women, fomentation caused a reduction in plasma suPAR levels, suggesting a role in antiinflammation or fibrinolysis. Taken together, fomentation might be a favorable approach for the prevention of obesity, diabetes and atherosclerosis-related diseases.

\section{Acknowledgments}

This study was supported by Grants-in-Aid for Scientific Research from the Japanese Ministry of Education, Science, Sports, and Culture (25504009, 24390511, 60623551).

\section{References}

1. Oda MI H, Ugajin T, Suzuki A, Tsuchiya S, Nagashima K, et al. (2006) Effects of warming the lower back with a heat and steam generating sheet on thermoregulatory responses and sensation. Japan J Biomet 43:43-50.

2. Chung J, Nguyen AK, Henstridge DC, Holmes AG, Chan MH, et al. (2008) HSP72 protects against obesity-induced insulin resistance. Proc Natl Acad Sci U S A 105: 1739-1744. [Crossref]

3. Noble EG, Shen GX (2012) Impact of exercise and metabolic disorders on heat shock proteins and vascular inflammation. Autoimmune Dis 2012: 836519. [Crossref]
4. Hui X, Lam KS, Vanhoutte PM, Xu A (2012) Adiponectin and cardiovascular health: an update. Br J Pharmacol 165: 574-590. [Crossref]

5. Yamauchi T, Iwabu M, Okada-Iwabu M, Kadowaki T (2014) Adiponectin receptors: a review of their structure, function and how they work. Best Pract Res Clin Endocrinol Metab 28: 15-23. [Crossref]

6. Morera P, Basiricò L, Hosoda K, Bernabucci U (2012) Chronic heat stress up-regulates leptin and adiponectin secretion and expression and improves leptin, adiponectin and insulin sensitivity in mice. J Mol Endocrinol 48: 129-138. [Crossref]

7. Outinen TK, Tervo L, Makela S, Huttunen R, Maenpaa N, et al. (2013) Plasma levels of soluble urokinase-type plasminogen activator receptor associate with the clinical severity of acute puumala hantavirus infection. PloS one 8: e71335. [Crossref]

8. Donadello K, Scolletta S, Covajes C, Vincent JL (2012) suPAR as a prognostic biomarker in sepsis. BMC Med 10: 2. [Crossref]

9. Thunø M, Macho B, Eugen-Olsen J (2009) suPAR: the molecular crystal ball. Dis Markers 27: 157-172. [Crossref]

10. Fuhrman B (2012) The urokinase system in the pathogenesis of atherosclerosis. Atherosclerosis 222: 8-14. [Crossref]

11. Eugen-Olsen J (2011) suPAR - a future risk marker in bacteremia. J Intern Med 270 29-31. [Crossref]

12. Eapen DJ, Manocha P, Ghasemzedah N, Patel RS, Al Kassem H, et al. (2014) Soluble urokinase plasminogen activator receptor level is an independent predictor of the presence and severity of coronary artery disease and of future adverse events. $J \mathrm{Am}$ Heart Assoc 3:e001118. [Crossref]

13. Conroy SM, Chai W, Lim U, Franke AA, Cooney RV, et al. (2011) Leptin, adiponectin, and obesity among Caucasian and Asian women. Mediators Inflamm 2011: 253580. [Crossref]

14. Arita Y, Kihara S, Ouchi N, Takahashi M, Maeda K, et al. (1999) Paradoxical decrease of an adipose-specific protein, adiponectin, in obesity. Biochem Biophys Res Commun 257:79-83. [Crossref]

15. Snehalatha C, Yamuna A, Ramachandran A (2008) Plasma adiponectin does not correlate with insulin resistance and cardiometabolic variables in nondiabetic Asian Indian teenagers. Diabetes Care 31: 2374-2379. [Crossref]

16. Yaghootkar H, Lamina C, Scott RA, Dastani Z, Hivert MF, et al. (2013) Mendelian randomization studies do not support a causal role for reduced circulating adiponectin levels in insulin resistance and type 2 diabetes. Diabetes 62:3589-98. [Crossref]

17. Lira FS, Rosa JC, Pimentel GD, Santos RV, Carnier J, et al. (2012) Long-term interdisciplinary therapy reduces endotoxin level and insulin resistance in obese adolescents. Nutr J 11: 74. [Crossref]

18. Yeung EH, Appel LJ, Miller ER 3rd, Kao WH (2010) The effects of macronutrient intake on total and high-molecular weight adiponectin: results from the OMNI-Heart trial. Obesity (Silver Spring) 18: 1632-1637. [Crossref]

19. Stephens RW, Pedersen AN, Nielsen HJ, Hamers MJ, Høyer-Hansen G, et al. (1997) ELISA determination of soluble urokinase receptor in blood from healthy donors and cancer patients. Clin Chem 43: 1868-1876. [Crossref]

20. Backes Y, van der Sluijs KF, Mackie DP, Tacke F, Koch A, et al. (2012) Usefulness of suPAR as a biological marker in patients with systemic inflammation or infection: a systematic review. Intensive Care Med 38: 1418-1428. [Crossref]

Copyright: (C2015 Nagai M. This is an open-access article distributed under the terms of the Creative Commons Attribution License, which permits unrestricted use, distribution, and reproduction in any medium, provided the original author and source are credited. 